Vol. 1, No. 2, pp. 93-99, 2020

\title{
Empowerment of Gunung Sari Village Community Groups, to Optimize the Potential of the Village Towards the Tourism Independent Village
}

\author{
Prihastuti Harsani ${ }^{1)}$, Adriana Sari Aryani ${ }^{2)}$, Tri Rahmadi \\ ${ }^{1,2}$ Prodi Ilmu Komputer FMIPA, Unviversitas Pakuan \\ Prihastuti.harsani@unpak.ac.id ${ }^{l)}$,adriana.aryani@gmail.com ${ }^{2)}$
}

\begin{abstract}
The tourism sector in Gunung Sari Village, Pamijahan District, Bogor Regency, is not the main sector in its community activities. The existence of natural tourism in the form of waterfalls, camping ground and hot springs is a potential for the village to realize the Bogor Regency Mission. Existing tour operators are not residents or village communities. The active participation of village communities has not been seen in the management, operational and maintenance of tourist attractions. The tour paramilitary group 20 can be an agent for villages to empower communities in the tourism sector. Srikandi Gunung Sari group is a community group that involves mothers and produces local food products in the form of banana chips and cassava. In an effort to increase the active participation of village communities in tourism activities in Gunung Sari Village, the empowerment of the Laskar Tourism Group 20 and Srikandi Gunung Sari was carried out through education, workshops, mentoring and facilitation activities. The main target of this activity is the village community who can independently manage, maintain and improve the tourism sector in Gunung Sari village towards a sustainable tourism independent village.
\end{abstract}

Keywords: Ecotourism, Community Groups, Education, Website Development

\section{Introduction}

Gunung Sari Village, Pamijahan District, Bogor Regency is one of the agricultural villages in the southeast, $25 \mathrm{~km}$ from the center of Bogor. The condition of the geographical area is almost $60 \%$ in the form of agricultural land so that most of their income and employment are as farmers. The population of Gunung Sari Village reaches around 11,000. Productive age of approximately 4000 people. The age of those who are still active in school is around 2000 people (Bogor Regency, 2012). Gunung Sari Village is one of the villages in the Pamijahan sub-district. Pamijahan District is one of the areas in Bogor Regency which is a major tourist destination. There are 15 villages, most of which are villages with a natural tourism priority. In Gunung Sari Village there are several tourist destinations that the village has to offer including 7 waterfall tours, camping ground, hot springs and water tracking. There are supporting facilities that are commonly used by local and foreign tourists including lodging, 
temporary resting and eating places. There are 18 large and small scale lodgings which most (94\%) are owned by residents outside Gunung Sari Village. Some communities and village governments are aware of the tourism potential of their villages (Fannel, 2015). This is based on the enthusiasm for the service activities that have been carried out previously, namely in 2015 and in 2016 through the Community Development activities conducted by the Computer Science Student Association (HIMAKOM) and the Computer Science Study Program. Several activities and efforts have been carried out to support Gunung Sari village to become an ecotourism area through community participation. These activities include the design of the Gunung Sari ecotourism web site (www.ekowisatagunungsari.com) and the formation of the Gunung Sari tourism driving community called LASKAR WISATA 20. The resulting output is the result of the Village Development Grant program conducted by HIMAKOM through funding by the Directorate of Learning and Ristekdikti Student Affairs in 2016. LASKAR WISATA 20 (LW-20) is a community group containing a joint group of students, youth groups and village leaders. In the service activities previously carried out LW20 has been equipped with the ability of basic computer skills and management of information media. The role of the LW-20 in the Gunung Sari tourism sector is as a driver of the community to be aware of tourism and the potential of the region it has. LW-20 is still carrying out routine activities in community empowerment especially youth groups by providing computer access and assistance especially in information technology. Gunung sari ecotourism web that has been provided by the University of Pakuan is still managed simply by LW-20. The existing web is still static, there is no twoway optimization between web visitors and the village, especially with regard to the Gunung Sari ecotourism (Tosida et al., 2019.a; 2019.b; 2019.c).

Gunung Sari Village already has several community groups that carry out activities related to family empowerment, including: PKK and Posyandu Groups, Gunung Sari Srikandi Business Group, and SPP groups. One of the active groups in implementing the family empowerment program is the Gunung Sari Srikandi Business Group. This group is a group that brings together a home-based business in processing banana chips. The srikandi group is chaired by the Lurah with representatives from several RTs in Gunung Sari Village, Pamijahan District. Raw materials obtained from banana plantations are found on residents' lands. Banana production in Gunung Sari Village is not yet a large scale production because most of the land in Gunung Sari village is paddy fields. The village's local products are produced and then sold in markets, stalls and restaurants around the village. There are opportunities for processing products that are more creative, attractive, healthy and can be produced on a large scale to later become the mainstay products of the Gunung Sari village for visitors (Tosida et al., 2018; 2020).

The people of Gunung Sari Village in managing their resources, especially natural resources, technology, and in managing their economy, still need support through empowering community elements. The beauty of nature and occasional tours, this of course becomes a problem that must be addressed. One way to overcome this problem is to provide supplies and knowledge about good and correct economic management to the people of Gunung Sari Village. So that their knowledge about the use of resources and technology, as well as economic management will be maximized, as well as generating creative ideas by using technology media in order to increase village income and progress.

Gunung Sari Village, Pamijahan District is still one of the nature-based tourist destinations. There are tourist areas including waterfalls, hot springs and camping ground which are targeted by visitors especially those from the capital. Tourism management is still done voluntarily by the village. Gunung Sari village tourism has the opportunity to become an independent tourism village that collaborates with community groups, business people, village government. This can at the same time create tourism with the Sapta Pesona. Salah satu unsur sapta pesona adalah lingkungan. Dalam pengembangan desa wisata lingkungan menjadi salau satu unsur yang harus dijaga (Regina, 2013). 
Activities undertaken in the realization of a tourist village are community empowerment through mastery of technology and economic improvement opportunities. Mastery of technology in the community can open up opportunities for villages to become open, known to the general public and increase cooperation with outside parties (Zainal, 2017; Tosida et al., 2017)).

Economic activities that arise due to the tourism village have a good effect on the financial condition of the family and ultimately the welfare of the village.

\section{Materials and Methods}

\subsection{Materials}

Materialas icluding: object, location, data \& informations, and tolls used in data analysis. Dalam kegiatan ini ma

\subsection{Methods}

Public service activities are carried out from February to April 2019. The place for the implementation of community service activities is Gunung Sari Village, Pamijahan District, Bogor Regency. In its implementation the tools used are personal computers and laptops. The existing computer set is a grant from the implementation of Community Service in 2017. The stages of the activities carried out can be seen in the figure 1 .

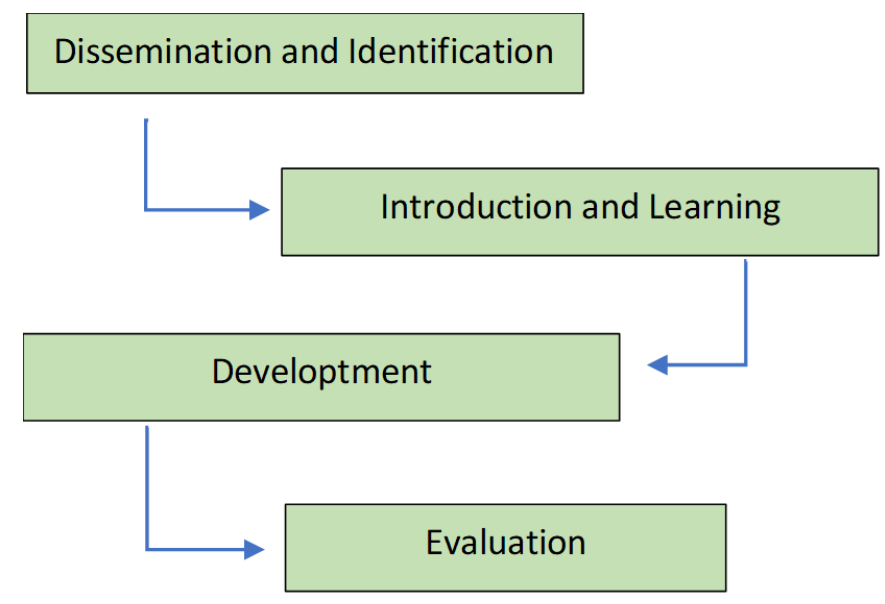

Figure 1. The stages of the activities

\section{Dssemination and Identification Stage}

In this dissemination phase, LASKAR WISATA 20 and villagers will be educated to develop village tourism and the role of village communities. Sosilisasi collected data on the potential and achievements of the village and Gunung Sari community to support the Tourism Village. In addition, data collection was also carried out on the number of tourist facilities available, whether commercial inns or residential homes that can be guaranteed homestays)(Syafii, 2015). In this activity potential and achievement will be generated, and an action plan for further activities. Potential cluster of tourism 
villages will be determined. For example, environment-based tourism, culture-based, craft-based and natural nuances. Based on community service activities carried out previously, it has been identified that the main cluster in Gunung Sari Village is nature-based tourism. To support and develop the tour, it is necessary to diversify the efforts of local residents to increase community participation in tourism in Gunung Sari and directly increase the economy and income of the village community (Dean, 2009)

\section{Learning and Provisioning Stage of Promotion Material}

The debriefing phase is intended for Gunung Sari villagers to be able to get to know how to market a product through a technological approach. Learning is carried out by providing training to youth groups and LW 20 to prepare interactive, interesting and able media to provide complete information on tourism in Gunung Sari Village. The LW 20 group, assisted by the PKM implementation team, provided training and mentoring to the Gunung Sari tourism mover group. Promotion of local products and culture in Gunung Sari village to support tourism development must involve businesses (Tosida et al., 2016.a; 2016.b).

\section{Promotion Media Development Stage}

Development stage Media promotion is a stage of web development and village profile video (Andi, 2003)

\section{Evaluasi and Monitoring Stage}

Monitoring is carried out by the PKM Team together with LW20. This activity is carried out in the context of monitoring the consistency of community partnership programs so that the vision will be achieved, namely the realization of the Tourism Independent Village by fulfilling all aspects of Sapta Pesona.

\section{Results and Discussion}

Activities that have been carried out are as follows:

\section{a. Socialization activities}

In the socialization activities carried out in conjunction with teaching activities. In this socialization explained more about the ecotourism in Gunung Sari Village, Pamijahan District to local youth. At the same time socializing the Gunung Sari ecotourism web. The parties involved were the Community Service Implementation Team (3 lecturers and 7 students), LW20 (20 people), the Gunung Sari Srikandi Business Group and the Village Government (including village secretaries, RT heads, hamlet heads. Socialization activities carried out can be seen in the figure 2 .
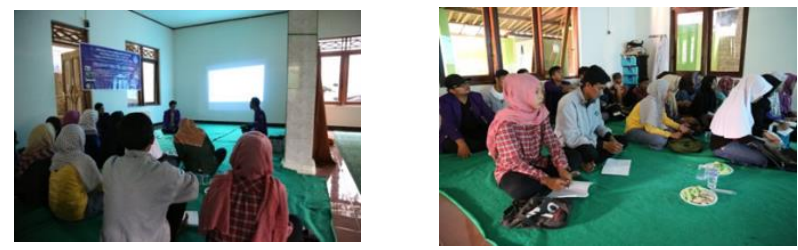
Figure 2. Socialization activities

Based on the results of the socialization and interview, the following are obtained:

1. Utilization of the existing promotional media is still not running optimally, this is because a set of PCs is the only mainstay of LW 20 to improve content, tourism-related administration is not functioning. Another necessity is a village profile video to illustrate the village's potential.

2. Tourist attractions that have been fully managed by local residents have been disregarded to the Province, so we need another mechanism for the recommendation of problems by the village government.Terdapat tempat wisata baru yang berpotensi untuk dikembangkan

3. Extracting information related to community activities that uphold local wisdom can be one of the village's flagship programs so that it can become part of the tour packages offered.

\section{b. Educational activities}

This youth activity was held on January 25 and February 1, 2019. This activity aims to strengthen the talisilaturahmi and strengthen faith and religion. In this youth activity there are usually events such as recitations, prayers, and lectures from religious teachers or local community leaders. This teaching activity was delivered to local youth and carried out for 3 nights. Material delivered and taught to teenage friends about technology between Microsoft Word, Microsoft Power Point, and photo editing. Local teenagers are very enthusiastic about this teaching activity because they are rarely on school benches getting material about computers. This teaching activity was carried out on January 26,27,28 and 2,3 February 2019. This activity aims to provide insights about computers. Because seeing the lack of learning about technology obtained by local teenagers in their school. At the same time providing provisions and understanding for friends when entering the workforce. Educational activities carried out can be seen in the figure 3. Level of acceptance of participant material can be seen in table 1 .
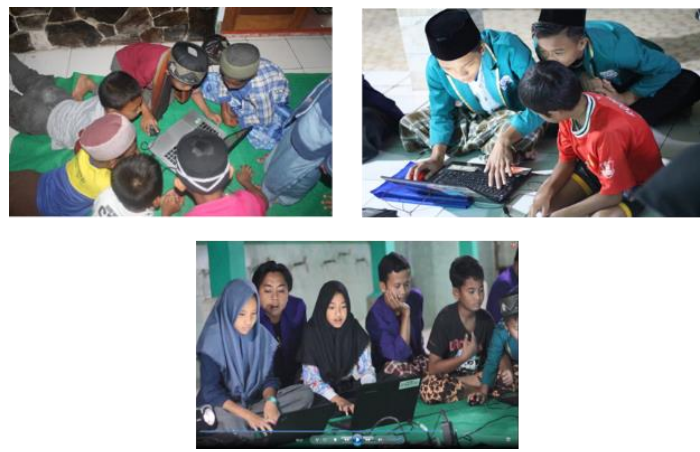

Figure 3. Educational activities

Table 1. Level of acceptance of participant material

\begin{tabular}{lllll}
\hline No & Interfal & Quantity & $\%$ & Kategori \\
\hline 1. & $85-100$ & 1 & 3.12 & Very Good \\
2. & $75-84$ & 4 & 12. & Good \\
3. & $65-74$ & 20 & 62.5 & Average \\
4. & $55-65$ & 7 & 21.8 & Bad \\
\hline Total & & 32 & & 100.00 \\
\hline
\end{tabular}


c. Information media production activities.

Information media will be made in the form of a website and village profile video. The web that will be developed is a web of design results that have been carried out in previous service activities, on the site www.ekowisatagunungsari.com. In this stage, updating the web is still static, news is not updated and the subscription period is extended for promotional needs. Web appearance can be seen in the figure 4 .
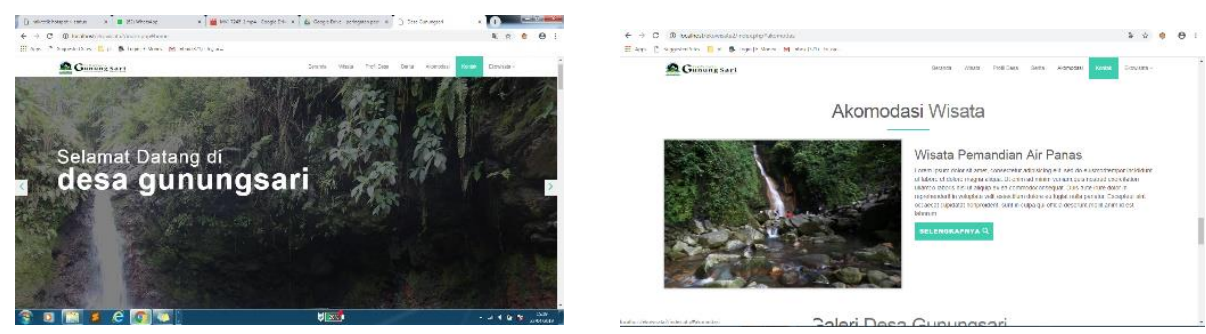

Figure 4. Web appearance

\section{Conclussion}

Ecotourism development activities in Gunung Sari involve two partners who have been formed through community service activities. The existence of partners plays an important role in the sustainability of the program. Partner members who always turn out to be a challenge for the servants to develop this program into a sustainable program. The program to enhance the ability of tourism management through information media management activities has given rise to a new program that can be an opportunity for village development, namely: 1). Establishment of an independent business data collection on water use by utilizing a computer program developed by the servants in collaboration with one of the members of Laskar Wisata 20,2). Srikandi Gunung Sari Business Group Empowerment through diversification of marawis culture by utilizing creative industries

\section{Acknowledgments}

Acknowledgments (if any) need to be delivered if there are institutions or individuals who have an important role to support the implementation of research and publications conducted.

\section{References}

Andi Dwi Riyanto. (2015). Making a Website as a Trusted Promotional Media (Pembuatan website sebagai media promosi yang terpercaya). Seminar Nasional Informatika, 2015 (semnasIF 2015) ISSN: 1979-2328 UPN "Veteran" Yogyakarta

Dean. (2009). Development Steps and Strategis for Tourism Villages Development (Langkah dan Strategi Pengembangan Desa Wisata ) https://deandanecro.wordpress.com/2009/12/23/langkah-dan-strategipengembangan-desa-wisata, last akses Juni , 2017

Fannel, D.A.(1999). Ecotourism : An Introduction.. Routlege, London and New York 
Regina B, \& Soemarno, (2013), Environmental Effects Of Ecotourism In Indonesia, Journal of Indonesian Tourism and Development Studies, Vol.1, No.3, September, 2013

Sastrayuda, \& Gumelar S. (2010). Concepts of Ecotourism Development. Hand Out Mata Kuliah Concept Resort and Leisure, Strategi Pengembangan dan Pengelolaan Resort and Leisure: Konsep Pengembangan Kawasan Desa Wisata

Syafii, M. \& Suwandono, D. (2015). Village Tourism Planning Using a Community Based Tourism (CBT) Concept Approach (Perencanaan Desa Wisata Dengan Pendekatan Konsep Community Based Tourism (CBT) Di Desa Bedono, Kecamatan Sayung, Kabupaten Demak). RUANG, VOLUME 1 NOMOR 2, 2015, 51-60 PISSN 1858-3881; E-ISSN 2356-0088 HTTP://EJOURNAL2.UNDIP.AC.ID/INDEX.PHP/RUANG

Tosida, E.T., Wahyudin, I., Andria, F., Djatna, T., Ningsih, W.K., \& Lestari, D.D. (2020). Business Intelligence of Indonesian Telematics Human Resource : Optimizing of Customer and Internal Balanced Scorecards. Journal of Southwest Jiaotong University, Vol. 55 No. 2, Apr (2020). DOI : 10.35741/issn.0258-2724.55.2.7. http://www.jsju.org/index.php/journal/article/view/528.

_Tosida E.T, Hairlangga, O., Amirudin, F., \& Ridwanah, M. (2018). Application of Decision Rules for Empowering of Indonesian Telematic Services SMEs. IOP Conference Series : Materials Science and Engineering. 332 (1), 012018.

Tosida, E.T., Ardiansyah, D., Walujo, A.D., Sofyandi, A. (2019.a). System Design of Augmented Reality Technology to Strengthen Sustainable Imaging of Kujang Products Based on Local Culture. International Journal of Recent Technology and Engineering (IJRTE), Vol. 8, Issue 4, Nov 2019, pp 5940- 5949.

Tosida, E.T., Andria, F., Wahyudin, I., Widianto, R., Ganda, M., \& Lathif, R.R. (2019.b). A Hybrid Data Mining Model for Indonesian Telematics SMEs Empowerment. IOP Conf. Ser. : Sci. Eng. 567. 012001.

Tosida E.T., Hermawan, Andria, F., Wahyudin, I., \& Djatna, T. (2019.c). Development Strategy for Telematics Small and Medium Industries in Indonesia. Jurnal Penelitian Pos dan Informatika, 2019, Vol 9 No. 1, 090104.

Tosida, E.T., Seminar, K.B., \& Herdiyeni, Y. (2016.a) . Atribut selection of Indonesian Telematic Services MSMEs Assisstance Feasibility, using AHP. Kursor 8 (2), 2016. DOI: http://dx.doi.org/10.21107/kursor.v8i2.1299.

Tosida E.T., Maryana, S., Thaheer, H., \& Damin, F.A. (2016.b). Visualization model of Small Medium Enterprises (SMEs) telematics services potentiality map in Indonesia. Published in:International Conference on Information \& Communication Technology and Systems (ICTS), 2015. Added toIEEExplorer. January $14^{\text {th }}$ 2016. doi : 10.1109/ICTS.2015.7379890.

Tosida E.T., Maryana, S., \& Thaheer, H. (2017). Implementation of Self Organizing Map (SOM) as Decision Support : Indonesian telematics services MSMEs empowerment. IOP Conference Series : Materials Science and Engineering, 166 (1), 012017.

Zainal Arifin, (2017), Tourism-Based Community Empowerment (Pemberdayaan Masyarakat Berbasis Pariwisata )(Studi Kasus Asongan Mandalika). Thesis. Univesitas Islam Negeri Sunan Kalijaga 